\title{
GIBa duten pertsonen kolektiboa eta komunikabideak: gaitasun mediatikoaren bidezko esku-hartze proposamena eta praktika egokiak ${ }^{1}$
}

\author{
Garbiñe Polo Iturraspe \\ Euskal Herriko Unibertsitatea (UPV/EHU) \\ garbine.polo@gmail.com
}

\section{Garbiñe Bereziartua Etxeberria}

Euskal Herriko Unibertsitatea (UPV/EHU)

garbine.bereziartua@ehu.eus

\begin{abstract}
Teknologien garapenak gizarte berri baten
\end{abstract} eraketa ekarri du, zeinean komunikabideak gure egunerokotasunean integraturik baitaude. Komunikabideak ezagutzaren sortzaile direnez gero, gizartean integraturik egon ahal izateko eta komunikabideek transmititu ditzaketen estereotipoei eta aurreiritziei aurre egiteko, biztanleriaren gaitasun mediatikoa garatzea garrantzitsua da. Esku-hartze honek bereziki fokua bazterketa-arrisku egoeran dagoen GIBa duten pertsonen kolektiboan jarri du. Lan honek 2017ko otsailetik apirilera Hiesaren Aurkako T4 Elkartean garatutako komunikabideen bidezko eta komunikabideei buruzko esku-hartze tailerrak jasotzen ditu. Ikerketaren helburu orokorrak bi dira: gizarte-bazterketa arriskuan dagoen kolektibo baten gaitasun mediatikoaren garapena eta, hori lortzeko emandako prestakuntzaren bidez sortutako ikus-entzunezko materiala erabiliz, Bilboko Hezkuntza Fakultateko ikasleengan sentsibilizazioa sustatzea. Lortutako emaitzek parte-hartzaileen gaitasun mediatikoaren garapena eta ikasleen sentsibilizazioa islatzen dute.

\section{GAKO-HITZAK:}

Gaitasun mediatikoa, GIB/HIESa, komunikabideak, alfabetatze digitala, ahalduntzea, gizarte-bazterketa arriskua.
El desarrollo de las tecnologías ha conllevado la creación de una nueva sociedad, de la que forman parte los medios de comunicación. Los medios crean conocimiento, por lo tanto, para estar integrado socialmente y enfrentarse a los estereotipos y prejuicios que transmiten, es importante desarrollar la competencia mediática. Este trabajo de intervención se ha centrado especialmente en el colectivo en riesgo de exclusión social formado por las personas con $\mathrm{VIH}$, recogiendo los talleres desarrollados sobre y mediante los medios de comunicación, de febrero a abril de 2017, en la Asociación T4 de Lucha contra el Sida. Los objetivos generales de la investigación son: desarrollar la competencia mediática de un colectivo en riesgo de exclusión social y, utilizando el material audiovisual creado mediante la formación impartida, suscitar la sensibilización del alumnado de la Escuela Universitaria de Magisterio de Bilbao. Los resultados obtenidos reflejan el desarrollo de la competencia mediática de los participantes y la sensibilización del alumnado.

\section{Palabras Clave:}

Competencia mediática, VIH/sida, medios de comunicación, alfabetización digital, empoderamiento, riesgo de exclusión social. 


\section{Sarrera}

Azken urteotan emandako teknologien garapenak hainbat aldaketa eragin ditu esparru sozial, ekonomiko eta kulturalean. Garapen horrek komunikabideei garrantzia eman die eta egungo gizartearen ezaugarri bereizgarrienetako batean bilakatu ditu. Komunikabideak gure eguneroko bizitzan integratu dira, horrek dakartzan ondorio ezberdinekin. Izan ere, komunikabideak ezagutzaren sortzaile eta errealitatearen ispilu dira; baina, beti ere, ahaztu gabe enpresen interes komertzialak, manipulatzaileak eta menperatzaileak dituztela abiapuntu. Zentzu horretan, prozesu horrenganako hausnarketa bideratzeko gai izango den biztanleria prestatu behar da.

Puntu horretan gaitasun mediatikoa jokoan sartzen da, funtsezkoa baita biztanleriaren autonomia kritikoa sustatzeko eta, horrekin batera, egitura zapaltzaileei aurre egitea baimenduko duen ahalduntze prozesua garatzeko. Prozesu horretan, hartzaileak prozesuaren parte-hartzaile aktiboak izateak prozesua osoagoa izatea ekartzen du, subjektuaren autonomia sozialaren maila handituz.

Alabaina, gizarte-kolektibo guztiak ez daude egoera berdinean eta, beraz, ez dituzte aukera berdinak gaitasun mediatikoaren garapena lortzeko orduan. Ildo horretan, gizarte-bazterketa arriskuan dauden kolektiboen gaitasun mediatikoa garatzeko eskuhartzea burutzea komenigarria ikusi dugu, kolektibo horiek komunikabideengandiko tratu negatiboa pairatzen dutelako, zaurgarriagoak bihurtuz eurei buruz sortu ditzaketen estereotipo eta aurreiritzien ondorioz. Egoera horren eta bere ondorioen kezkatik sortzen da lan honekiko interesa eta justifikazioa.

Lanari dagokionez, zati ezberdinetan banaturik egituratzen da. Lehenik eta behin, oinarri teorikoa aurki dezakegu, zeinean gaiaren inguruan ikertu duten ikerlarien lanak aztertzen baitira. Segidan, lan hau egiteko erabili den metodologia zein izan den deskribatzen da. Jarraian, gizarte-bazterketa arriskuan dagoen kolektibo baten gaitasun mediatikoa garatzea helburu duen esku-hartzearen planteamendua eta garapena azaltzen dira. Eta, azkenik, ikerketaren emaitzak eta ondorioak aurkezten dira, etorkizunari begirako alderdiak aintzat hartuz.

\section{Aurrekari teorikoak}

\subsection{Komunikabideetan eta komunikabideekin heztearen garrantzia}

Areak (2004) dioenez, jadanik topiko bat da baieztatzea egun inguratzen gaituen testuinguru soziala, ekonomikoa eta kulturala modu erradikal eta funtsezko batean aldatu direla azkeneko urteotan. XX. mendeko azkeneko laurdeneko ordenagailuen agerpenak, kontsumo zerbitzu tertziarioen eskariaren hedapenak, baliabide naturalen eta industrializazioaren ondorio negatiboen kontzientziazioak eta informazioaren antolaketa eta banaketa era berriek, beste faktore batzuekin batera, garatutako herrialdeetan "hirugarren iraultza industrialaren" garapena ekarri zuten. Eta, hori guztia, egitura eta prozesu ekonomikoetan, bai bizitza eta kultura moduen eta ereduen bai harreman sozialen eraldaketa garrantzitsua eta sakona eragiten ari da.

Castellsek (1996) antzeko ideia defendatzen du, XX. mende bukaeratik informazioaren eta teknologien inguruan antolatzen den historiaren tartean bizi garela informatzen baitu. Autorearen arabera komunikabideak eta, batez ere, komunikazio prozesuen oinarri dira gure kulturaren barneko ikusentzunezko komunikabideak.

Horren inguruan, Baumanek (2003) adierazten duen moduan, jariakortasuna eta likidotasuna metafora egokiak dira modernitatearen historiaren egungo tartearen izaera irudikatzeko. Autoreak dioenez, gizarte kapitalistaren trazu edo ezaugarriak aldatu egin dira eta aldatzen jarraitzen dute, modernizatuz doaz, hori dela eta, ez dago balio solidorik eta gizabanakook gero eta independenteagoak bilakatzen ari gara; modernitate solido eta benetako bat sortzearen aukerak eskuetatik ihes egiten digu, edozein likidok bezala.

Vasquezek (2008) Baumanek adierazitako "denboraldi likidoaren" esaerari egiten dio erreferentzia, eta modernitate "solido" batetik (egonkorra, errepikakorra) "likido” batera (malgua, aldakorra) aldaketa eman dela esaten du; egitura eta eredu sozialek ez dutela behar besteko iraupenik biztanleriaren ohiturak errotzeko; eta, konturatu gabe, eraldaketa eta galerak pairatu ditugula. Iraungipenaren eta limurtzearen erreinupean bizi garela esaten du, pilaketa ez funtzionalaren eta indibidualismoaren garaian.

Zentzu horretan, Loscertales eta Nuñezek (2008) baieztatzen dute teknologien bidezko komunikabide sozialak egungo gizartearen ezaugarri bereizgarrien bilakatu direla. Diotenez, komunikabideen alde zein kontra egon, ezin dugu ukatu horiek daukaten eragina mendebaldeko kulturaren eraketan. Modu horretan, komunikabideek egungo elkarrekintza psikosozialetan duten eragina sailkatzerakoan aipatutako autoreek komunikabideek lau esparrutan eragiten dutela adierazten dute: ezagutza sozialean (identitatea, atribuzioak, errepresentazioak), sozializazioan (hizkuntza, pentsamenduaren garapena, ohiturak eta ereduen imitazioa), eragin sozialean (boterea eta autoritatea, konformismoa eta limurtzea) eta jarreren sorkuntzan eta aldaketan (estereotipoak eta aurreiritziak).

Halaber, Perezen (2004) eta Castellsen (1996) arabera, begi-bistakoa da teknologia berriek eta komunikabideek bai kulturan bai eta esparru sozial ezberdinetan duten eragin handia. Ideia horrekin lotuta, Castellsek (ibidem) adierazten du komunikazioak kultura baldintzatzen eta helarazten 
duela, eta, horren ondorioz, historian zehar sortutako uste eta kodeak sistema teknologiko berriagatik eraldatu egiten direla. Aipatutako bi autoreen iritziz, ezagutza era berri bati buruz hitz egin dezakegu: "pentsamendu bisualaren garaia"-ri buruz hain zuzen ere. Batik bat, komunikabideek ez dutelako soilik ezagutzaren hedapenaren eta zirkulazioaren inguruko arreta galarazten, sozializazioarentzat ere eszenatoki erabakigarria eratzen dutelako baizik. Gaiarekin jarraituz, Postmanen (1985: 354) idatzi bat berreskuratu dezakegu, ondokoa dioena "no vemos [...] la realidad [...] como es, sino como son nuestros lenguajes. Y nuestros lenguajes son nuestros medios de comunicación. Nuestros medios de comunicación son nuestras metáforas. Nuestras metáforas crean el contenido de nuestra cultura".

Perezek (2004) adierazten duenez, informazioaren eta komunikazioaren teknologiek eta komunikabideek ezagutza eraikitzen dute, eta gure ingurunean dauden mito berrien sortzaileak eta bitartekariak dira. Horiek errealitatea irudikatu edo sinestarazteko erabiltzen dituzten moduak ezagutu egin beharko lituzkete erabiltzaileek. Autoreak dioenez, agerikoa da, beraz, komunikazioaren eta informazioaren kontsumitzaile eta erabiltzaile berriak kontzienteki alfabetatzeko esku-hartzea baimenduko duten proposamen didaktikoen garapena, beti ere egun bizi garen gizartearen barneko egoeren eta elkartruke komunikatiboen araberako erabileraren kontzientzia osoaz eta horien gaitasun komunikatiboa indartuz.

Horrenbestez, komunikabideetan eta komunikabideen bidezko hezkuntzak abiapuntu izan behar du haien errealitatearen inguruan hausnartuko duten, errealitate hori ulertzeko baliabideak egokituko dituzten eta errealitate hori birsortzea baimenduko duten gaitasun mediatikoak, moralak, eta sozialak garatzeko (Perez, 2004).

\subsection{Alfabetatzea, gaitasun mediatikoa eta alfabetatze digitala}

Denboran zehar alfabetatze terminoaren inguruko ikusmolde anitz egon dira eta, termino hori, momentu bakoitzaren beharrizanetara moldatuz eta bilakatuz joan da (Caldeiro eta Aguaded, 2015). Areak, Grosek eta Marzalak (2008) adierazten dutenez, indibiduo edo talde sozial bakoitzaren alfabetatzea baldintzatu egiten dute bizi den testuinguru historikoaren ezaugarri kulturalek, sozioekonomikoek eta teknologikoek. Alfabetatzea garai bakoitzaren barneko kultura sozial nagusiaren beharren, baliabideen eta beren eraldatze prozesuen arabera aldatzen eta eboluzionatzen den praktika soziala da; beraz, ez da talde edo klase sozial hegemonikoen interesetatik at dagoen produktu neutroa. Alfabetatzea, hau da, ezagutzaren ekoizpenerako, arakatzerako eta sarbiderako gaitasuna, beti izan da gutxiengoek osatutako taldeen identitatean eta ezberdintze sozialean eragin duen tresna. Horrez gain, alfabetatzea kodifikazioaren eta informazioaren banaketarako asmakizun teknologiko berriek eragindako eraldaketa kulturalekin batera eraldatuz joan da.

Alfabetatze kontzeptuaren inguruan literatura ugari aurki dezakegu, bai eta ikuspuntu eta joera ezberdinak ere. Adibidez, Buschmanek (2010) testuingurua edo oinarri soziala azpimarratzen ditu. Izan ere, autoreak adierazten du alfabetatzea gai ekonomiko eta politikoa dela, eta zentzua emango dion praktika sozial baten barnean kokatzen dela.

Beste autore batzuek gizartean integratzeko metodo moduan ulertzen dute. Hala nola, Area, Gros eta Marzalentzat (2008) alfabetatzea indibiduo batek modu esanguratsu batean informazioaren era adierazgarriak (bai ikus-entzunezko edo baliabide digitalean, baita baliabide inprimatuan ere) kodifikatzeko eta deskodifikatzeko duen gaitasuna da.

Ideia horren alde agertzen dira Perez eta Aguaded (2000) ere. Autore hauen arabera, egungo gizartean alfabetatua egoteko ikus-entzunezko baliabideak kontuan hartzea beharrezkoa da: gure garaiko ikasketa prozesuak ikus-entzunezko kodean ematen direlako.

Zentzu berean, Gutierrez eta Tynerek (2012) alfabetatzea gizarte digitalaren bizitzarako prestakuntza moduan ulertzen dute. Alabaina, Gavara de Carak (2015) adierazten duenez, alfabetatzea ez da nahikoa, biztanleriaren gaitasuna garatu behar da, egun alfabetatze digitalaren bidez lortzen dena.

Alfabetatze digitalari dagokionez, Gutierrez eta Tynerrek (2012) diote ezin daitekeela teknologien kontsumitzaile eta erabiltzaileak sortzeko baliabide bilakatu; alfabetatzeak kritikoa, askatzailea eta gizabanakoak duin izateko behar duela, enpresen interes komertzialetatik eta menperatzaileetatik at.

Area eta bere kideek (2008) diotenez, ikusentzunezko alfabetatzeak gizabanakoak ikusentzunezko testuak sortzeko eta analizatzeko eta komunikabideen produktuen kontsumo kritikorako gaitasuna duten subjektu moduan heztea du helburu. Modu zehatzago batean, Caberok (2001) dio ikus-entzunezko alfabetatzearen bidez igorlearen eta hartzailearen artean lotura sortu behar dela sinbolo ikoniko-bisualak eta ikonikosoinuzkoak erabiliz, modu bereizian edo elkarrekin. Halaber, Area eta bere kideek (2008) diotenez, ikus-entzunezko alfabetatzearen barnean hiru ikuspuntu garatu daitezke, hala nola: heziketa gramatikala (kodeen, elementuen eta ikusentzunezko hizkuntzaren egiturak), dimentsio teknologiko-materiala (tresneriaren maneiuaren irakaskuntza) eta komunikabideen mezu eta edukien analisi sozioideologikoa (komunikabide ezberdinek helarazitako mezuen analisia).

Mastermanek (1993) dioenez, ikus-entzunezko alfabetatzea funtsezkoa da biztanle guztiek boterea 
erabili eta erabaki arrazionalak hartzeko; bai eta aldaketaren agenteak izan eta komunikabideetan modu aktiboan parte-hartzeko ere. Horregatik, Areak (2004) dioenez, beharrezkoa da komunikabideen ikus-entzunezko alfabetatzea, testuinguru sozial mediatiko batean modu zentzudunean moldatuko diren biztanleak trebatzeko.

Mastermanek (1993: 40), beraz, gaitasun mediatikoa garatzea ikus-entzunezko eta alfabetatze digitalaren bitartez funtsezkoa ikusten du biztanleriaren autonomia kritikoa sustatzeko. Autoreak kontzeptua honela definitzen du:

Uno de los objetivos primeros de la educación audiovisual no debe ser obtener de los alumnos la competencia de reproducir fielmente las ideas, los puntos de vista críticos o la información que le proporcione el profesor [...]. La labor, realmente importante y difícil [...] consiste en desarrollar en los alumnos la confianza en sí mismos y la madurez critica para que sean capaces de aplicar juicios críticos a los documentos de los textos que encuentren en el futuro.

Horren inguruan Perezek (2004) dio komunikabideak irakaskuntza prozesuetan integratzea komunikabide horiez hausnartzeko (bere hizkuntza eta informatzeko era ezberdinak) hezkuntza integralaren gakoa direla.

Ferrések (2005) adierazten duenez, gaitasuna, modu orokorrean, testuinguru jakin batean beharrezkotzat jotzen diren ezagutzen eta jarreren konbinazioa da. Modu horretan, Ferrés eta Piscitelli (2012) aintzat hartuz, kontzeptuak erreferentzia egiten die oinarrizko sei dimentsiori (lengoaia-, teknologia-, elkarrekintza-prozesuak, eraikitze- eta transmisio-prozesuak, ideologia eta baloreak eta alderdi estetikoak) eta horien adierazleekin lotutako ezagutzen, jarreren eta trebetasunen menperatzeari.

Gavara de Carak (2015) dio komunikabideek eta teknologia berriek inguratzen duten errealitateak biztanleriaren ezjakintasun kontzientea eta komunikabideetara modu kritiko eta oso batean sarbidea izateko gaitasun eza ekarri dituztela. Horrekin lotuta eta Martinez eta Vasquez (2016) aintzat hartuz, kontzientzia kritikoa eskuratzea funtsezko alderdia da gizarte-mailan biztanleen bizitzak eraldatuko dituzten ekintzak sortzeko.

\subsection{Gizarte-bazterketa arriskuan dauden kolektiboen gaitasun mediatikoa garatzearen garrantzia}

Coordinadora Estatal de VIH-Sida eta Grupo de Trabajo sobre Tratamientos del VIH-k (2015) dioenez, komunikabideen funtzio soziala ikuspuntu didaktiko eta informatzaile batetik planteatu daiteke, gakoa izan daitekeena gizarte-bazterketa arriskuan aurkitzen diren kolektiboentzako (adibidez, GIBa duten pertsonak), ukapena eta bazterketa soziala ekiditeko.
Coordinadora Estatal de VIH-Sidak (2011) adierazten du horretarako beharrezkoa dela kolektibo horiekin esku-hartzen duten erakundeen zein kolektiboaren barneko pertsonen presentzia eta iritzia hedatzea, haien ezagutzak, esperientzia pertsonalak eta kolektiboarekin erlazionatutako arazo sozialak adierazteko.

Gizarte-bazterketa arriskuan bizi diren pertsonek pairatzen duten estigma da, pertsona horien arretan, esku-hartzean eta prebentzioan, arazo eta oztopo gehien sortzen dituen elementuetako bat (Romeo eta Marchi, 2015). Hori dela eta, estigmarik eta bazterketarik gabeko gizarte baten eraikuntzan beharrezkotzat hartzen da biztanleriaren pentsaeran aldaketa bat ematea, zeinaren bitartez kolektiboen inguruan errotutako estigma desegin eta deseraiki ahal izango baita (Bazurto, 2014). Alabaina, aldaketa hori soilik posible izango da bazterketa-arriskuan dauden kolektiboaren barneko pertsonak "erabiltzaile" pasibo izateari uzten diotenean eta protagonistaren rola hartzen dutenean (Carballeda, 2002).

Modu horretan, erabiltzaileak komunikabideen aurrean kritiko bilakatzen dira, mezu berriak sortzeko gai izanik (Renes, Garcia eta Ramirez, 2013) eta aldaketarako komunikazioa sortuz; horrela, kultura-aniztasunetik eta dialogo horizontaletik pentsatzeko eta komunikazioa sortzeko zein komunikabideak kontsumitzeko era ezberdinak garatzen dira, enpresa mediatikoen eta industria kulturalengandik interesetatik aldenduta (Valencia eta Magallanes, 2015).

\subsection{Ikus-entzunezko hezkuntza eta Gizarte Hezkuntza: lau esperientzia adierazgarri}

Gertrudix-Barrio, Galvez, Said-Hung eta DuranMedinak (2016) adierazten dutenez, informazioaren gizarteak eta komunikabideek informazioa tratatzeko, kontsumitzeko eta ekoizteko modu ezberdinak sortu dituzte. Autoreen arabera, biztanleak kontsumitzaile eta ekoizle bezala ulertzeak alfabetatze digitala eta gaitasun mediatikoa bezalako oinarrizko alderdietan maila sozial ezberdinen existentzia nabarmentzen du.

Ikus-entzunezko alfabetatzearen, alfabetatze digitalaren eta, ondorioz, gaitasun mediatikoaren bidezko ahalduntze prozesuaren lau adibide adierazgarri aipatuko ditugu jarraian.

Lehenik eta behin, Homeless Film Festival ${ }^{2}$ esperientziari erreferentzia egin diezaiokegu. Esperientzia hori Manchesterren (Erresuma Batuan) 2011. urtean sortutako zinemaldia da eta etxerik gabeko pertsonekiko sentsibilizazioan murgilduta dagoen mundu-mailako zinemaldi bakarra da. Euskal Herriari dagokionez, Bizitegi elkartearen bitartez eta Bilboko Udalaren laguntzarekin, Bilbon festibalaren lagin zinematografikoa estreinatu zen 2016ko azaroaren 5 ean, non antzerkigintzaren eta zinearen bitartez garatutako sentsibilizazioaren bidezko

\footnotetext{
${ }^{2}\langle$ http://www.homelessfilmfestival.org〉.
} 
gizarteratze sozialaren inguruko jardunaldia burutu zen. Kasu horretan, Bizitegi elkartearen barneko erabiltzaileak agente zein protagonistak izan ziren, haiek sortutako film laburra eta antzezlana aurkeztu baitziren, beste ekimen batzuen artean.

Bigarrenez, Rise \& Shine Productions esperientzia hezitzailea aipatu dezakegu. Gobernuz kanpoko eta irabazi asmorik gabeko erakunde komunitarioa da, New Yorken sortutakoa 1985ean. Bertan gazteekin eta haien komunitateekin lan egiten da komunikabideen hizkuntzaren erabilpen sortzailearen bitartez. Helburua da gazte horiek komunikabide sozialekin eta hezkuntzarekin, komunitatean duten harreman pasiboa aldatzea eta lider gazte eta indartsu bilakatzea. Proposamen hezitzaile bat da eta xedea da gazteek sorkuntza kritikoaren bidezko ikusentzunezko ekoizpena burutzea, garapen pertsonal eta komunitariorako eredu eraginkor moduan. Modu sakonago batean adieraziz, esku-hartze horren bitartez subjektuei komunikabideen hizkuntza irakurtzen eta sentimendu, errealitate eta arazo propioak ikuspuntu kritiko batetik irudikatuko dituzten irudiak sortzen irakasten zaie (March, 1997).

Hirugarren adibide moduan har ditzakegu garapenerako lankidetzaren inguruan burutzen diren zenbait proiektu. Jenatsch-ek eta Bauer-ek (2014) burututako gidan oinarrituz, proiektu horiek garapenerako komunikazioaren inguruan egituratzen dira. Gidan adierazten denez, garapenerako komunikazioa eragin sozial eta politikorako erreminta da. Parte-hartzea eta eraldaketa soziala sustatzen ditu pertsonarteko zein komunitateko komunikazioa eta teknologia berriek eskainitako baliabideak erabiliz. Horren adibidetzat, Jenatsch eta Baueren (2014) gidan agertutako eta La Habanan (Kuban) aurrera eramandako esperientzia aipatu dezakegu, "Documental Tierralismo", hain zuen ere. Esperientziaren helburua zonalde bateko protagonisten istorioak, antolaketa metodoak eta Nekazaritza Lokalaren Berrikuntza Proiektuaren eragin soziala adieraztea da. Dokumentalaren bitartez, protagonistak ahalduntzea eta proiektua sustatzea lortu dute.

Horrez gain, Jenatsch eta Bauer-ek (2014) jasotako esperientziekin jarraituz, oso eredugarria izan daiteke Bolivian burututako kanpaina lokala: "Mi municipio es buena noticia”. Esperientzia horren bitartez, 2009. urtetik hainbat komunikabide lokalek kanpainak garatu dituzte (La Paz eta Cochabamban) osasuna, hezkuntza, biolentziarik gabeko bizitza, ingurumena, gazteen parte-hartzea, gestioa eta gardentasuna eta antzeko gaiak jorratuz. Kanpaina horiek komunikazioaren (komunikabideen) eta mobilizazio akzioen (tailerrak, jardunaldiak, lehiaketak...) bidez burutzen dira. Kanpainek komunikatzaileek haien udalerrietan rol aktiboago bat izatea lortu dute, bai eta biztanleriak mobilizazio sozialetan, publikoetan eta politikoetan parte-hartzea ere.

Zentzu horretan, March-ek (1997) dio partehartzaileek gaitasunak lortu behar dituztela komunikabideak ezagutzeko, haiekiko ikuspegi kritikoa garatzeko eta euren beharrak, arazoak, mundua, eta errealitatea adierazteko erabili beharko duten berariazko lengoaia menperatzeko. Eta, hori, prestakuntza-prozesuaren erronka dela, komunikabideen eragina are negatiboagoa delako bazterketa-arriskuan dauden talde sozialetan.

\subsection{Ikerketa-galderak}

Esku artean dugun gaiaren inguruko bibliografia errebisatu ondoren, hainbat kezka sortu zaizkigu eta esku-hartze honen bitartez ondoko ikerketa-galderak erantzutea izan da gure helburua:

1. Gizarte-bazterketa arriskuan dagoen kolektibo bati prestakuntza emanez bere gaitasun mediatikoa garatzea posible izango litzateke?

2. Gizarte-bazterketa arriskuan dagoen kolektiboa, prestakuntzaren bitartez, sentsibilizazio-kanpaina bat egiteko materiala sortzeko gai izango litzateke?

3. Gizarte-bazterketa arriskuan dagoen kolektiboak jasotako prestakuntzaren bidez sortutako produktuak gizarteko beste partaide batzuen sentsibilizazioa bultzatzea posible izango al litzateke?

\section{Metodologia}

Gure ikerketa esku-hartze forman gorpuztu dugu. Horren diseinua egiteko esku-hartzearen baitako faseak garatuz joan gara: diagnostiko fasea, planifikazioa, esku-hartzea bera eta guztiaren balorazioa. Hurrengo atalean deskribatuko ditugu fase bakoitzaren xehetasunak.

\subsection{Helburuak}

Bi helburu nagusi lortu nahi izan ditugu: batetik, GIBa dutenen kolektiboaren gaitasun mediatikoa garatzea; eta, bestetik, gai horrekiko sentsibilizazio soziala piztea. Baina helburu orokor horiek helburu zehatzagoetan xehatu ditugu:

1. GIBa duten pertsonen kolektiboaren gaitasun mediatikoa garatzea.

a. Ikus-entzunezko alfabetatzea integratzen duen prestakuntza burutzea.

b. GIB/HIESa duten pertsonen kolektiboaren inguruko sentsibilizazio-kanpaina batean erabiltzeko ikus-entzunezko bat sortzea.

c. Parte-hartzaileen ahalduntzea bultzatzea.

Ikerketaren helburu nagusia Hiesaren Aurkako T4 elkartearen Zure Enea eguneko zentroko onuradunen gaitasun mediatikoa garatzea da. Horretarako, beharrezkoa da gaitasun hori garatzeko prestakuntza-saio batzuk diseinatzea 
eta burutzea, parte-hartzaileen beharren arabera. Horrez gain, gaitasun mediatikoaren garapenaren bitartez ahalduntze prozesua sustatu daitekeen ikusi nahi da; horretarako, ezagutza teoriko horiei aplikazio soziala emango zaie ikus-entzunezko produktu baten sorkuntza bideratuz. Ildo horretatik, prozesuaren pauso guztiek parte-hartzaileen ahalduntzerako baldintzak emango dituzte.

\section{Sentsibilizazio soziala:}

a. Bideoaren laguntzaz sortutako solasaldiak sentsibilizazioa sortzen duen ikustea.

Beste helburu orokor bat Bilboko Irakasleen Unibertsitate Eskolako ikasleen artean GIB/ HIESa duten pertsonen kolektiboaren inguruko sentsibilizazioa lantzea da. Zentzu horretan, gaitasun mediatikoaren garapenaren bitartez sortutako bideoarekin unibertsitateko gazteen sentsibilizazioa lantzea posible den ikusi nahi dugu.

\subsection{Lagina}

Esku-hartze honetako lagina bi kolektibok osatu dute: batetik, Hiesaren Aurkako T4 elkartearen Zure Enea eguneko zentroko onuradunak; eta, bestetik, Bilboko Irakasleen Unibertsitate Eskolako ikasleak:

- Lehenengo taldea Hiesaren Aurkako T4 elkartearen Zure Enea eguneko zentroko 45 eta 57 urte bitarteko 12 helduk osatu dute. Partehartzaileen gehienak gizonak izan dira (\% 70), batezbesteko adina 51 urtekoa izanik.

- Bigarren taldea Bilboko Irakasleen Unibertsitate Eskolan antolatutako sentsibilizazio-jardunaldian parte-hartutako ikasleek osatzen dute. Partehartzaile guztiak Gizarte Hezkuntzako graduko ikasleak izan dira: 27 guztira. 20-43 urte bitarteko hogei emakume $(\% 75)$ eta zazpi gizon (\% 25), batezbesteko adina 24 urte izanik.

\subsection{Neurtzeko tresnak}

Esku-hartzean zehar hainbat tresna erabili ditugu prozesuaren diseinua nola egin jakiteko, prozesuaren garapena ikuskatzeko eta emaitzak neurtzeko.

Erabilitako tresnak 4 galdetegi eta talde dinamika bat izan dira. Galdetegiei dagokienez, bi Zure Enea eguneko zentroko erabiltzaileentzako sortu da. Zure Eneako erabiltzaileek galdetegi bat esku-hartzearen hasieran bete dute haien gaitasun mediatikoaren diagnostikoa egiteko eta prestakuntza diseinatzeko beharrezkoak genituen datuak lortzeko; bigarrena, prestakuntza-saio guztiak burututa bete dute, hasieran lortutako datuekin konparaketa bat egiteko eta esku-hartzearen beraren balorazioa egiteko. Beste bi galdetegiak sentsibilizazio-jardunaldirako sortu dira. Jardunaldi horretan parte-hartutako ikasleek galdetegi bana bete dute jardunaldiaren hasieran eta bukaeran. Azkenik, esku-hartzearen atal teorikoaren eta praktikoaren barnean burututako tailer bakoitza bukatzean, saioa ixteko talde dinamika bat burutu da.

- Diagnostiko fasean erabilitako galdetegiak:

- T4 elkartearen Zure Enea eguneko zentroko erabiltzaileen diagnostikoa egiteko Likert eskalako galdetegi bat erabili da. Galdetegiaren diseinuari dagokionez, itemak 5 atal nagusitan sailkatu dira eta guztira 35 galdera formulatu dira: datu pertsonalei buruzko 3 item, ikus-entzunezkoen prestakuntza propioari buruzkoak beste 3 , ikus-entzunezko komunikazioaren kontsumoari buruzkoak ere beste 3, ikusentzunezko gaitasunei buruzkoak 11 eta, azkenik, komunikabideen gaineko gaitasun kritikoari buruzkoak 15.

- Sentsibilizazio-jardunaldian parte-hartu duten ikasleen diagnostikoa egiteko Likert eskalako galdetegi bat erabili da. Jardunaldia hasi aurretik bete duten galdetegia 14 itemez osatuta zegoen: datu pertsonalei buruzko 3 item eta ikertu nahi den gaiarekiko sentsibilizazioari buruzkoak 11.

- Esku-hartzean zehar egin den prestakuntzaebaluazioa egiteko erabili den tresna.

- Fase teorikoaren ebaluazioari dagokionez, saio bakoitzaren amaieran talde dinamika bat burutu da non parte-hartzaileen artean erronda bat egin den, tailerraren inguruan eta haien sentsazio/egoeraren inguruan hitz egiteko eta haien iritzia adierazteko, beti ere ateratako ideiak etorkizunerako hobekuntzarako proposamen eta aldaketa bezala integratuz.

- Balorazio-fasean erabili diren galdetegiak:

- T4 elkartearen Zure Enea eguneko zentroko erabiltzaileekin egindako esku-hartzearen balorazioa egiteko Likert eskalako galdetegi bat erabili da. Galdetegiaren diseinuari dagokionez, sei atal nagusi sailkatu dira eta berrogeita zortzi galdera formulatu dira. Kasu honetan, diagnostiko fasean burututako galdetegiaren egitura mantendu da, atal berri bat gehituz: datu pertsonalei buruzko itemak 3 izan dira, ikus-entzunezkoen prestakuntza propioari buruzkoak beste 3 , ikus-entzunezko komunikazioaren kontsumoari buruzkoak ere beste 3, ikus-entzunezko gaitasunei buruzkoak 11, komunikabideen gaineko gaitasun kritikoari buruzkoak 15, pertzepzio pertsonalari (gehitutako atala) buruzkoak 11 eta, azkenik, iruzkinak edo iritzia adierazteko bi galdera itxi eta ireki bat egin dira.

- Sentsibilizazio-jardunaldian parte-hartu duten ikasleekin egindako esku-hartzearen balorazioa egiteko Likert eskalako galdetegi bat erabili da. Jardunaldiaren ostean bete duten galdetegian datu pertsonalei buruzko 3 item, ikertu nahi 
den gaiarekiko sentsibilizazioa neurtzeko 14 item eta iruzkin edo ekarpenak egin ahal izateko galdera ireki bat.

\section{Esku-hartzea}

\subsection{Diagnostiko fasea}

Ikerketa honen helburuak azaltzean ikusi dugunez, gure esku-hartzeak bi kolektiborengan eragin nahi du. Hori dela eta, diagnostikoa egiteko garaian xedetalde horietako bakoitzari begiratu diogu.

\subsubsection{GIBa duten pertsonen kolektiboaren gaitasun mediatikoa garatzeko esku-hartzearen diagnostikoa}

Esku-hartzea Hiesaren Aurkako T4 elkartearen "Zure Enea” eguneko zentroan eraman da aurrera. "Zure Enea” 2002. urtean sortu zen auto-laguntzarako espazio bat da, eta terapia nahiz antolaketarekin lotutako esparruez haratagoko zerbitzuak eskaintzen ditu. Zentroan hainbat zerbitzu eskaintzen dira, besteak beste: arreta sozio-hezitzaile indibiduala zein taldekoa, tratamenduei buruzko informazioa eta orientazioa, denbora librearen dinamizazioa, orientazio legala nahiz juridikoa eta prestakuntzatailerrak. "Zure Enean" hamabost pertsonarentzako plazak daude eta erabiltzaile bakoitzak behar beste denboran jarrai dezake bertan ${ }^{3}$.

Zure Enean bazterketa sozialean edo arriskuan aurkitzen diren gizabanakoekin esku-hartzen da. Pertsona horiek GIB/HIES edota Hepatitisa ezan dezakete eta drogen kontsumitzaileak izan daitezke. Horretarako gizarteratze sozialerako laguntza bio-psiko-soziala eskaintzen da arreta plan indibidualizatuen bidez (bazterketa eta GIB/HIESan aditu den talde diziplina anitzekoen eskutik), beti ere, oinazea gutxitzeko edo arriskuak minimizatzeko ikuspuntua abiapuntutzat izanik. Izan ere, kontuan hartzekoa da GIB/HIESa duten gizabanakoek ez dutela egoera hori isolaturik bizi; normalean drogen kontsumoa, sexu-praktika ezegokiak, familialoturekiko haustura, preso-oiak izatea eta bestelako egoerekin lotuta egon ohi baitira

Egoeraren diagnostikoa egiteko erabilitako galdetegiari erreparatuz, bertako 12 erabiltzaileen ikasketa-mailari dagokionez \% 50 ak lehen mailako ikasketak burututa ditu. \% 75ak ez du ikusentzunezko prestakuntzarik jaso. Eta, zentzu berean, gehienek ez dute ikus-entzunezko praktikarik burutu (\% 88). Horrez gain, parte-hartzaileen \% 53 ak ez du ikus-entzunezkoen baliabideen gaineko gaitasun kritikorik. Kontsumitutako ikus-entzunezkoei dagokienez, telebista \% 30ak, irratia \% 30ak, prentsa $\%$ 25ak eta Internet \% 15ak kontsumitzen dituzte, eta kontsumo hori pasiboa da \% 10oaren. Telebistaren edo interneten kontsumoari dagokionez, gehien

3 Iturria: Asociación T4 de Lucha contra el Sida-Hiesaren Aurkako T4 Elkartea (〈http://asociaciont4.com〉). ikusten dituzten saioak albistegiak (Teleberria $\%$ 10oak), fikziozkoak (filmak \% 87,5ak eta telesailak $\%$ 10oak), kiroletakoak (kirol-ekitaldiak \% 75ak) eta ikuskizunezkoak (lehiaketak \% 62,5ak) dira. Ikusentzunezko kodeak \% 16ak soilik ezagutzen ditu. Eta \% 62ak ez dauka erreminta errazak (Internet, YouTube, Vimeo, blogak) erabiltzeko gaitasunik. $\% 100 a$ ez da gai ikusten ikus-entzunezko produktu bat sortzeko eta \% 88ak ez ditu ezagutzen ikusentzunezko araudiak ez betez gero erreklamazio legalak egiteko aukerak.

\subsubsection{Sentsibilizazio soziala lortzeko esku- hartzearen diagnostikoa}

Sentsibilizazio-jardunaldia Bilboko Irakasleen Unibertsitate Eskolan burutu da, Leioan. Eskola hori Euskal Herriko Unibertsitatearen barneko fakultate bat da, non Gizarte Hezkuntzako, Haur Hezkuntzako eta Lehen Hezkuntzako graduak eskaintzen diren. Esan bezala, jardunaldian parte-hartu zuten 27 subjektuak Gizarte Hezkuntzako ikasleak izan ziren.

Galdetegiaren bitartez lortutako datuei dagokienez, ondokoa erakusten dute: \% $74 \mathrm{ak} \mathrm{ez} \mathrm{du} \mathrm{GIBa}$ eta HIESa ezberdintzen; \% 54ak ez du GIBa duen pertsonarik ezagutzen; \% 11ak ez lizkioke bi muxu emango GIBa duen pertsona bati; \% 52ak ez lituzke sexu-harremanak izango GIBa duen pertsona batekin; \% 22ak ez luke edalontzirik partekatuko GIBa duen pertsona batekin eta \% 3oak uste du komunikabideek ez duela kolektiboarekiko estereotiporik sortzen.

\subsection{Planifikazio fasea}

Esku-hartzearen diseinuak hiru atal izan ditu:

1. Atal teorikoa: Parte-hartzaileen gaitasun mediatikoa garatzeko helburuarekin diseinatutako prestakuntza-saioak burutu dira, guztira 75 minututako 9 saio.

2. Atal praktikoa: Parte-hartzaileek ikus-entzunezko produktu bat, hau da, sentsibilizazio-bideo bat sortu dute, eskuratutako ezagutzak aplikatuz. Horretarako, 75 minutuko 3 saio burutu dira.

3. Atal soziala: Sortutako ikus-entzunezko produktua EHUko Bilboko Irakasleen Unibertsitate Eskolan aurkeztu da, elkarteko parte-hartzaileak ahaldundu diren bitartean, jardunaldiaren partehartzaileak sentsibilizatuz. Saio bakarra egin da, 90 minutuko iraupena izan du eta gaiarekin lotutako edukiak landu dira esku-hartzearen aurreko ataletan sortutako ikus-entzunezkoa ardatz hartuta.

\subsubsection{Fase teorikoaren eta praktikoaren diseinua}

Esku-hartzearen lehenengo bi atalak eguneko zentroan burutzen diren beste tailerrekin batera 
integratu dira. Kasu honetan, tailerraren izena "Desenfocando los Medios" izan da eta eguneko zentroaren abilezia sozialen programan integratu da. Esku-hartzea hiru hilabetetan zehar garatu da (otsailetik apirilera) eta saioak astean behineko maiztasunarekin burutu dira, salbuespenak salbuespen, eguneko zentroaren beharrizanak errespetatuz. Saio bakoitzak ordu eta laurdeneko (75') iraupena izan du.

Aurreratu den moduan, lan honen helburuetako bat gizarte-bazterketa arriskuan dagoen kolektibo baten gaitasun mediatikoa garatzea da, kolektibo horren ahalduntzea ahalbideratzeko. Horretarako, tailerrak “egitearen bidez ikastearen" printzipioan oinarritu dira, eta teoria eta praktika integratuta helarazi dira, motibazioa bultzatzeko asmoz. Hori kontuan izanik eta galdetegiaren emaitzak ikusita, atal teorikoaren barnean bederatzi saio antolatu dira eta saio bakoitzean gai ezberdinak jorratu dira, guztien arteko jarraipena bermatuz. Atal teorikoaren diseinua 1. taulan azaltzen da.

\section{1. taula. Prestakuntza-saioaren diseinuaren eskema}

\section{Kontrol soziala}

Helburua: Teknologien bidez estatu eta enpresek biztanleriarekiko eragiten duten kontrol sozialaz kontzientzia hartzea.

1 Deskribapena: gaia hiru autoreren materialak erabiliz landu da. Lehenik eta behin bideo labur bat ikusi da (Peirano, 2015), ondoren kontrol sozialaren adibide bat ezagutu da (Zubiria, 2016) eta, azkenik, gaiari buruzko artikulu bat aztertu da ideia orokorrak ateraz eta landuz (Ramonet, 2009).

Zer kontsumitzen duzu?

Helburua: Gutako bakoitzak dauzkagun komunikabideen kontsumo ohiturez hausnartzea eta jarrera kritikoa sustatzea.

2 Deskribapena: Estatu Espainolaren barneko komunikazio taldeen inguruko informazioa ezagutu da (zeintzuk diren, zein motatakoak diren, zein komunikabideren jabe diren eta zein ideologia dagoen atzetik). Ondoren, norberaren komunikabideen kontsumo ohiturak aztertu dira.

\section{Komunikabideen jabeak}

Helburua: Komunikabideen inguruko jarrera kritikoa lantzea, horien atzetik dauden jabeak, jabeek burututako manipulazio-prozesuak, finantzazio-iturriak eta irtenbideak aztertuz.

Deskribapena: Hiru azpiatal landu dira; lehenik eta behin, komunikabideen jabeak eta kontroldun konpainiak aztertu dira (erabiltzen dituzten manipulazio-prozesuak ezagutuz eta urteetan emandako aldaketen berri izanez). Jarraian, komunikabideen finantziazio iturriak landu dira eta, azkenik, komunikabideen iturriekiko jarrera kritikoa nola garatu aztertu da. Saioari bukaera emateko, jorratutako edukiak laburbiltzen dituen bideo bat ikusi da (Parenti, 2008; Chomsky eta Hernan, 1990; Serrano, 2010; Producciones CMI y Paz Con DignidadOMAL, 2014).

Desinformatzeko teknikak

Helburua: Desinformazio-teknikak zer diren ezagutzea eta adibide praktikoekin horien erabilpenaz ohartzea.

4 Deskribapena: Komunikabideetan erabiltzen diren desinformazio-teknika ezberdinak landu dira “Zein teknika da?" lehiaketaren bitartez. Bertan, tekniken adibideak agertu dira, eta 3 itemen artean egokia aukeratu behar izan da (Garcia Aviles, 2015).

\section{Telebista}

Helburua: Telebistaren barneko programa motak ezagutzea, programazioa nola burutzen den jakitea eta programaziorako estrategiez ohartzea.

5 Deskribapena: Saioa bi ataletan banatu da; lehenik eta behin telebistaren alderdia jorratu da (programa motak) kazetari eta telebistaanalista baten bideo baten bitartez (Cubells, 2014). Ondoren, programazioaren gaia landu da nortzuek, nola eta zertarako egiten duten aztertuz (Cubells, 2006). Azken atal honetan telebistaren programazioaren analisi-jarduera burutu da.

\section{Publizitatea}

Helburua: Publizitatearen gaineko jarrera kritikoa garatzea, bere benetako funtzioa zein den aztertuz eta erabiltzen diren limurtze6 faktore ezberdinak ezagutuz.

6 Deskribapena: Publizitateak gizabanakoongan daukan eragina aztertu da limurtze-teknikak eta kontsumorako lagungarriak diren faktoreak ezagutuz. Jarraian erotismoaren erabilera publizitatean analizatu da. Azkenik, "kontra-publizitatea” eta horren adibideak aztertu dira (Ipublimarketing, 2014; Mastrodomenico, 2011; Zapata, 2014).

\section{Publizitatea (spot)}

Helburua: Spot publizitarioek biztanleriarengan daukaten eraginaz eta transmititzen dituzten balore eta estereotipoez ohartzea.

7 Deskribapena: Spot publizitarioen sorreraren zergatia eta betetzen duten funtzioa aztertu dira. Ondoren, parte-hartzaileek aukeratutako bi spot aztertu dira irizpide ezberdinei erreparatuz. (Bebea, 2015; Cubells, 2013; Ferrés, 1994).

\section{Genero ikuspuntua}

Helburua: Komunikabideak sexismoaren menpe dauden kontzientzia hartzea eta horien eragina ekiditen saiatzea.

8 Deskribapena: Saioa bi zatitan banatu da. Alde batetik, ikus-entzunezkoen "sindromeak" (matxistak) deritzenak landu dira, Bechdellen testaz lagunduta. Bigarren zatiari dagokionez, komunikabideek biolentzia matxisten aurrean duten jarrera aztertu da. (Pons eta Martinez, 2010; Izagirre, 2011; Asensio eta Fernandez, 2008; Bechdel, 2006). eraginari erreparatuz. Ondoren, audientziak telebistan duen papera zein den eta bere neurketa nola egiten den ezagutu dira (Garcia Aviles, 2015; McComs, 2006). 
Atal praktikoaren diseinua 2. taulan ikus daiteke.

2. taula. Fase praktikoaren diseinuaren eskema

\begin{tabular}{|c|l|}
\hline 1 & $\begin{array}{l}\text { Ikus-entzunezko kodeak eta muntaketa programak } \\
\text { Helburua: Ikus-entzunezko produktu bat burutzeko } \\
\text { oinarrizko elementuak ezagutzea. } \\
\text { Deskribapena: Saioarekin hasteko, ikus-entzunezko kode } \\
\text { ezberdinak eta horien barneko elementuak jorratu dira } \\
\text { modu teorikoan. Ondoren, irudien, testuen eta irudi- } \\
\text { testuaren harremanen analisia burutu da (Aparici, Garcia eta } \\
\text { Fernandez, 20o6). }\end{array}$ \\
\hline 2 & $\begin{array}{l}\text { Bideoaren prestaketa } \\
\text { Helburua: Ikus-entzunezko produktuen sorkuntzarako } \\
\text { gaitasunak lantzea eta burutuko den bideoaren alderdi } \\
\text { orokorrak zeintzuk izango diren erabakitzea. } \\
\text { Deskribapena: Sortu beharreko sentsibilizazio-bideoaren } \\
\text { story-board bat egin da. }\end{array}$ \\
\hline 3 & $\begin{array}{l}\text { Bideoaren sorkuntza } \\
\text { Helburua: Ikus-entzunezko produktu bat sortzen ikastea. } \\
\text { Deskribapena: Sortu nahi den produktua grabatu eta } \\
\text { muntatu da. }\end{array}$ \\
\hline
\end{tabular}

Iturria: Egileen lana.

Bideoaren edizioari dagokionez, lan hori eskuhartzea aurrera eraman duen ikertzailearen esku gelditu da.

\subsubsection{Atal sozialaren diseinua}

Fase teorikoaren prestakuntzari esker eta fase praktikoan sortutako ikus-entzunezko produktuaren bitartez, fase sozialaren diseinua burutu ahal izan da. Jardunaldia Bilboko Irakasleen Unibertsitate Eskolak eskaintzen duen jardunaldiak burutzeko tartean (asteazkenetan, 10.30etatik 12.0oak arte) egin da. Jardunaldiaren izena "GIB/HIESa eta komunikabideak. Gizarte-bazterketa arriskuan dagoen kolektibo baten esku-hartze proposamena" izan da eta ordu eta erdiko (90') iraupena izan du. 3. taulan ikus daitezke xehetasunak.

\subsection{Esku-hartze fasea}

Esku-hartzea hainbat hilabetetan zehar garatu da. Abenduan esku-hartzearen planteamendua eta onarpena eman ziren. Ondoren, urtarriletik maiatzera esku-hartzearen hiru faseen burutzapena eman zen. Urtarrilean zehar esku-hartze osoaren prestaketa gauzatu zen eta otsailetik apirilera bitartean atal praktiko eta teorikoa burutu ziren; fase sozialari dagokionez, maiatzean gauzatu zen, esku-hartze osoari itxiera emanez.

\subsection{Esku-hartzearen balorazio-fasea}

Esku-hartzearen helburuak bete al diren ikusteko, lortutako emaitzak aztertu ditugu. Emaitza horiek guztiak ikerketa-galderen arabera antolatuta azalduko ditugu.

\section{1. ikerketa-galdera: Gizarte-bazterketa arriskuan dagoen kolektibo bati prestakuntza emanez bere gaitasun mediatikoa garatzea posible izango litzateke?}

Gure esku-hartzearekin lortu ditugun emaitzen arabera, gizarte-bazterketa arriskuan dagoen kolektibo bati prestakuntza emanda, bere gaitasun mediatikoa garatu egin da.

Gaitasun mediatikoaren garapena gertatu den ala ez ikusteko zenbait galdera prestakuntzaren aurretik eta ondoren egin dizkiegu, batzuk eta besteak alderatzeko. 4. taulan ikus ditzakegu jasotako emaitzak.

3. taula. Fase sozialaren diseinuaren eskema

Sentsibilizazio-jardunaldia

Helburua: Bilboko Irakasleen Unibertsitate Eskolako ikasleen artean GIB/HIESa duen kolektiboaren inguruko sentsibilizazioa sustatzea. Deskribapena: Saioan zehar lau gai orokor landu dira: GIB/HIESa, Hiesaren Aurkako T4 elkartea, Gradu Amaierako Lana izan den eskuhartzearen aurkezpena eta hor sortutako ikus-entzunezkoa, eta GIB/HIESaren inguruko kasu praktikoen berri ematea. Azkenik, saioaren dinamizatzaileak sortutako kasu praktikoen bitartez, aurretik jorratutako edukien inguruko hausnarketa egin da.

Iturria: Egileen lana.

4. taula. Gaitasun mediatikoaren garapena prestakuntzaren hasieratik amaierara

\begin{tabular}{|c|c|c|c|c|c|c|c|c|}
\hline \multirow{2}{*}{ Itemak } & \multicolumn{2}{|c|}{ Ezer ez } & \multicolumn{2}{|c|}{ la ezer ez } & \multicolumn{2}{|c|}{ Zerbait } & \multicolumn{2}{|c|}{ Asko } \\
\hline & Pre & Post & Pre & Post & Pre & Post & Pre & Post \\
\hline Ikus-entzunezko piezen gaineko hausnarketa kritikorako ohitura duzu? & 38 & 0 & 0 & 27 & 62 & 73 & 0 & 0 \\
\hline Komunikabideek erabilera sozialik izan dezaketela uste al duzu? & 13 & 0 & 13 & 0 & 37 & 82 & 37 & 18 \\
\hline $\begin{array}{l}\text { Ikus-entzunezko araudiak ez betez gero erreklamazio legalak egiteko aukerak } \\
\text { ezagutzen dituzu? }\end{array}$ & 88 & 64 & 12 & 18 & 0 & 18 & 0 & 0 \\
\hline $\begin{array}{l}\text { Ikus-entzunezkoen erreklamaziorako aukerak ezagutzeak boterea eskaintzen } \\
\text { dizula uste duzu? }\end{array}$ & 88 & 27 & 12 & 18 & 0 & 37 & 0 & 37 \\
\hline Zure kontsumo mediatikoaren ohituren gainean hausnartzeko ohiturarik duzu? & 25 & 9 & 0 & 27 & 63 & 55 & 12 & 9 \\
\hline
\end{tabular}

Iturria: Egileen lana. 
Ikus-entzunezko piezen gaineko hausnarketa kritikorik batere egiten ez zutenak $\% 38$ ziren prestakuntzarekin hasi aurretik; baina prestakuntzaren ondoren, neurri xumean bada ere, guztiek erantzun dute hausnarketa egiten dutela.

Komunikabideek izan dezaketen erabilera sozialari buruz galdetutakoan, prestakuntzaren aurretik parte-hartzaileen laurdena pasak erantzun zuen komunikabideek erabilera sozialik batere ez edo ia ezer ere ez dutela, beste herena pasak uste zuen zerbait izan dezaketela eta beste heren bat da komunikabideek erabilera sozial handia izan dezaketela uste zuena. Prestakuntzaren ondoren, parte-hartzaileen \% 82ak komunikabideek sozialki zerbait eragin dezaketela uste du eta \% 18ak asko eragin dezaketela.

Ikus-entzunezko araudiak ez betez gero erreklamazio legalak egiteko aukera batere ez edo ia batere ez zituzten ezagun prestakuntzaren aurretik; ondoren, $\%$ 18ak erantzun du gai horren inguruan zerbait badakiela.

Ikus-entzunezkoen erreklamaziorako aukerak ezagutzeak boterea eskaintzen duela uste al duten galdetutakoan, prestakuntza egin aurretik partehartzaileen \% 100ak "ezer ez" edo "ia ezer ez" erantzun zuen; prestakuntza egin ondoren partehartzaileen arteko \% 74ak "zerbait" edo "asko" erantzun du.

Eta beren kontsumo mediatikoen ohituren gainean hausnartzeko ohiturarik ba al duten galdetutakoan, prestakuntza egin aurretik \% 75ak "zerbait “ edo "asko" erantzun zuen; prestakuntzaren ondoren erantzun horiek \% 64ak eman ditu.

Gaitasun mediatikoaren inguruan prestakuntzaren aurretik eta ondoren jasotako emaitzak alderatu eta gero, prestakuntza egin ostean ikasitakoaren gainean dauzkaten pertzepzioak ikus daitezke 5. taulan.
Tailerretan proposatutako gaien inguruko analisigaitasuna garatu duen ideiarekin oso ados dago parte-hartzaileen $\% 73$, eta ados $\% 27 a$. Ildo beretik, prestakuntzarekin ezagutzak eta gaitasunak eskuratu dituen ideiarekin ados dago parte-hartzaileen $\% 55 \mathrm{a}$ eta oso ados \% 36a. Horrez gain, gainontzeko partehartzaileen gaitasuna hobetu dela uste du partehartzaileen \% 91k. Eta prestakuntzan zehar norbere ideiak modu egokian komunikatu eta defendatzeko gai izan dela erantzun du parte-hartzaileen arteko \% 91ak.

Beraz, gure emaitzetan ikusi dugunez, gizartebazterketa arriskuan dagoen kolektibo bati prestakuntza emanez bere gaitasun mediatikoa garatzea posible izan dela esan dezakegu.

\section{2. ikerketa-galdera: Gizarte-bazterketa arriskuan dagoen kolektiboa, gai izango litzateke prestakuntzaren bitartez, sentsibilizazio-kanpaina bat egiteko materiala sortzeko?}

Bigarren ikerketa galdera hori baieztatu egin ahal izan dugu, izan ere, gaitasun mediatikoak garatzeko prestakuntza jasotako GIBa duten pertsonen kolektiboa sentsibilizazio-kanpaina bat egiteko materiala sortzeko gai izan da. Horren erakusle da parte-hartzaileek sortutako ikus-entzunezko materiala (Polo, 2017).

Horrekin batera, prestakuntza horren barnean sentsibilizazio-materiala sortzerako orduan alderdi ezberdinak garatu direla erakutsi nahi du 6. taulak.

Prestakuntza egin aurretik ikus-entzunezkoak sortzeko erreminta errazak erabiltzeko gaitasun pixka bat bazeukala parte-hartzaileen arteko \% 25ak erantzun du; prestakuntzaren amaieran kopuru hori $\%$ 55era igo da.

Ikus-entzunezko produktu sinple bat sortzeko gai direla uste al duten galdetutakoan, parte-

5. taula. Prestakuntza-tailerra egin ondoren parte-hartzaileen pertzepzioak

\begin{tabular}{|c|c|c|c|c|}
\hline Itemak & $\begin{array}{c}\text { Erabateko } \\
\text { desadostasuna }\end{array}$ & $\begin{array}{c}\text { Ez } \\
\text { ados }\end{array}$ & Ados & $\begin{array}{l}\text { Erabat } \\
\text { ados }\end{array}$ \\
\hline Tailerretan proposatutako gaien inguruko analisi gaitasuna garatu dut. & 0 & 0 & 27 & 73 \\
\hline Tailerren bidez ezagutza eta gaitasun propioak eskuratu edo hobetu ditut. & 9 & 0 & 55 & 36 \\
\hline Tailerretako gainontzeko parte-hartzaileen gaitasunak hobetu direla behatu dut. & 0 & 9 & 73 & 18 \\
\hline Tailerretan nire ideiak modu egokian komunikatzeko eta defendatzeko gai izan naiz. & 0 & 9 & 82 & 9 \\
\hline
\end{tabular}

Iturria: Egileen lana.

6. taula. Ikus-entzunezkoak sortzeko gaitasunaren garapena

\begin{tabular}{|l|c|c|c|c|c|c|c|c|}
\hline \multirow{2}{*}{ Itemak } & \multicolumn{2}{|c|}{ Ezer ez } & \multicolumn{2}{|c|}{ la ezer ez } & \multicolumn{2}{|c|}{ Zerbait } & \multicolumn{2}{c|}{ Asko } \\
\cline { 2 - 10 } & Pre & Post & Pre & Post & Pre & Post & Pre & Post \\
\hline Erreminta errazak erabiltzeko gaitasuna. & 13 & 0 & 62 & 45 & 25 & 55 & 0 & 0 \\
\hline Ikus-entzunezko produktu sinple bat sortzeko gai zarela uste duzu? & 63 & 9 & 25 & 27 & 12 & 64 & 0 & 0 \\
\hline $\begin{array}{l}\text { Ikus-entzunezko produktu bat sortzeko irudia zein soinua integratzea } \\
\text { baimentzen duen ordenagailu-programaren bat ezagutzen duzu? }\end{array}$ & 100 & 0 & 0 & 9 & 0 & 82 & 0 & 9 \\
\hline
\end{tabular}

Iturria: Egileen lana. 
hartzaileen \% 88ak ez zuen bere burua horretarako gai ikusten prestakuntzaren hasieran; prestakuntza amaitutakoan \% 64ak neurri batean bere burua horretarako gai ikusten du.

Ikus-entzunezkoak sortzeko ordenagailuko programaren baten ezagutzari buruz galdetutakoan, prestakuntzaren aurretik ez zuen parte-hartzaileen arteko inork horrelakorik ezagutzen; prestakuntzaren ondoren, horren gaineko ezagutza-mailaren pertzepzioak gora egin du parte-hartzaile guztien kasuan.

\section{3. ikerketa-galdera: Gizarte-bazterketa arriskuan dagoen kolektiboak jasotako prestakuntzaren bidez sortutako produktuak gizarteko beste partaide batzuen sentsibilizazioa bultzatzea posible izango al litzateke?}

Gizarte-bazterketa arriskuan dagoen kolektiboak jasotako prestakuntzaren bidez sortutako produktuak sentsibilizazioa sortu dezakeela baieztatu dezakegu, aldaketa esanguratsuak nabaritu ditzakegu jardunaldian parte-hartutako ikasleen artean. Hori erakusten dute 7. taulan ikus ditzakegun datuek.

Sentsibilizazio-saioan parte-hartu duten subjektuen arteko \% 96ak GIB/HIESarekiko kezka daukatela erantzun dute saioarekin hasi aurretik, eta datu hori \% 10ora igo da saioaren amaieran. Baina GIBaren eta HIESaren arteko ezberdintasuna ezagutzen dutela esan duten subjektuak \% 26 izan dira saioaren aurretik eta $\% 100$ saioaren ondoren.
GIBa duen pertsona batekin edalontzia partekatzearekin guztiz ados zeuden partehartzaileak \% 34 ziren saioaren hasieran eta kopuru hori \% 71ra igo da saioaren bukaeran. Eta GIBa duen pertsona batekin sexu-harremanik izango luketenak $\% 52$ ziren saioaren hasieran, baina \% 26 amaieran.

Hala ere, \% goetik gora izan dira saioaren hasieratik GIBaren inguruko hausnarketa-jarrera daukatela esan dutenak. Eta beste horrenbeste gertatu da komunikabideek GIBa duten pertsonen inguruko estereotipoak sortzen dituzten ideiarekin: saioa egin aurretik ere \% goetik gora parte-hartzailek uste zuten baietz. Baina komunikabideek diskriminazioa eta ezagutza okerrak sorrarazten dituzten albiste sentsazionalistak ematen dituztela parte-hartzaileen arteko \% 59ak uste zuen hasieran eta kopuru hori $\% 85$ era igo da amaieran.

Saioa egin aurreko eta ondorengo erantzunak alderatuta ikusi ditugun datuez gain, saioa egin ondoren parte-hartzaileen arteko \% 96ak esan du orokorrean gaiaren inguruko bere ezagutzak garatu egin direla eta \% 10ok esan du gaiaren inguruko bere sentsibilizazioa garatu egin dela. Eta, horrekin batera, parte-hartzaileen arteko \% 10oak esan du GIBa duten pertsonen gaitasun mediatikoa garatzeak ondorio positiboak izan ditzakeela.

Adierazitakoaren analisi orokorra eginez, kasu honetan gizarte-bazterketa arriskuan dagoen kolektibo batek bere kolektiboari buruz sortutako materialak sentsibilizazioa sortu du gizarteko beste partaide batzuengan.

7. taula. Unibertsitateko ikasleen sentsibilizazioa

\begin{tabular}{|c|c|c|c|c|c|c|c|c|}
\hline \multirow{2}{*}{ Itemak } & \multicolumn{2}{|c|}{$\begin{array}{c}\text { Erabateko } \\
\text { desadostasuna }\end{array}$} & \multicolumn{2}{|c|}{ Desadostasuna } & \multicolumn{2}{|c|}{ Ados } & \multicolumn{2}{|c|}{ Erabat ados } \\
\hline & Pre & Post & Pre & Post & Pre & Post & Pre & Post \\
\hline GIB/HIESa kezkatzen nauen gaia da & 0 & 0 & 4 & o & 74 & 59 & 22 & 41 \\
\hline GIBa eta HIESaren ezberdintasuna ezagutzen dut. & 52 & o & 22 & o & 11 & 30 & 15 & 70 \\
\hline $\begin{array}{l}\text { Edalontzia partekatuko nuke GIBa duen pertsona } \\
\text { batekin. }\end{array}$ & 6 & 4 & 16 & 11 & 44 & 14 & 34 & 71 \\
\hline $\begin{array}{l}\text { GIBa duen pertsona batekin sexu-harremanak izango } \\
\text { nituzke. }\end{array}$ & 22 & 15 & 30 & 11 & 33 & 56 & 15 & 18 \\
\hline GIBaren inguruko hausnarketa jarrera daukat. & 0 & 0 & 8 & 7 & 70 & 26 & 22 & 67 \\
\hline $\begin{array}{l}\text { Komunikabideek diskriminazioa eta ezagutza okerrak } \\
\text { sorrarazten dituzten albiste sentsazionalistak ematen } \\
\text { dituzte. }\end{array}$ & 0 & 0 & 41 & 15 & 0 & o & 59 & 85 \\
\hline $\begin{array}{l}\text { Komunikabideek GIBa duten pertsonen inguruko } \\
\text { estereotipoak sortzen dituzte. }\end{array}$ & 0 & 4 & 0 & 4 & 30 & 7 & 70 & 85 \\
\hline $\begin{array}{l}\text { GIBa duten pertsonen gaitasun mediatikoa garatzeak } \\
\text { ondorio positiboak izan ditzake. }\end{array}$ & - & 0 & - & 0 & - & 11 & - & 89 \\
\hline $\begin{array}{l}\text { Orokorrean, gaiaren inguruko nire ezagutzak garatu } \\
\text { dira. }\end{array}$ & - & 0 & - & 4 & - & 26 & - & 70 \\
\hline Gaiaren inguruko nire sentsibilizazioa garatu da. & - & 0 & - & 0 & - & 41 & - & 59 \\
\hline
\end{tabular}




\section{Ondorioak eta aurrera begirakoak}

Gure ikerketan bildutako emaitzak atal teorikoan ikusitako ideiekin uztartuz, besteak beste Perezek (2004) azpimarratzen zuen beharrezkoa zela komunikazioaren eta informazioaren kontsumitzaile eta erabiltzaileak kontzienteki alfabetatzeko proposamen didaktikoak garatzea. Komunikabideetan eta komunikabideen bidezko hezkuntza oinarrizkoa zela bizi garen errealitatearen gainean hausnartu, ulertu eta hori birsortzeko gaitasunak eskuratzeko. Eta Areak, Grosek eta Marzalak (2008) bereziki gizartetik baztertzeko arriskuan dauden komunitateak hartzen zituzten kontuan, argudiatuz alfabetatzea beti izan dela desberdintasun sozialak areagotzeko balio izan duen tresna.

Guk burutu dugun esku-hartzean bi ideia horiek erakusten zuten bideari eutsi diogu, bazterketaarriskuan zegoen kolektibo baten gaitasun mediatikoa garatzeko proposamen didaktikoa gauzatuz. Emaitzen atalean ikusi ahal izan dugun moduan, gure ikerketako parte-hartzaileek jorratutako edukien gaineko hausnarketarako eta analisi kritikorako jarrera eskuratu dute haien gaitasun mediatikoa garatzen zen heinean. Hori gertatzearekin batera, ikusi dugu kontzientzia kritiko horren garapenean, kolektiboaren ahalduntzerako baldintzak eman direla. Torresek (2009) dioenez, ahalduntzea kontzientziazio prozesu bat da non subjektua bere gaitasunez ohartzen den. Horri esker, subjektuak bere burua eta bere testuingurua eraldatzeko bere akzioak indartzen ditu.

Gaitasun mediatikoa garatzea eta ahalduntzea gertatzea oinarri izan dira Carballedak (2002) aipatzen zuen erabiltzaile aktiboaren rola hartu eta sentsibilizazio-kanpaina bat aurrera eramateko ikus-entzunezko materiala sortzeko. Burututako esku-hartzearen bitartez espazio mikrosozial batean espazio soziokomunikatibo bat garatu da, non subjektuek rol aktiboa bereganatu duten, eta hori Mendoza, Belarra eta Bustosen (2014) eta Carballedaren (2002) arabera ahalduntzerako prozesu horretan funtsezkoa da. Material hori sortzeaz gain, gizarteko beste partaide batzuen sentsibilizazioa bultzatzeko erabili ere egin da, gizarte-bazterketa arriskuan bizi diren pertsonek jasaten duten estigma desegitea xede izanik. Gure ikerketaren bidez begiztatu ahal izan dugu gizartebazterketan edo arriskuan dagoen kolektibo batek bere errealitatea erakusten duen ikus-entzunezko produktu bat sortzeko gai izan denean eta produktu hori gizarte-mailan aurkeztu duenean, kolektiboarekiko sentsibilizazioa eman dela, horrekiko estereotipo eta diskriminazio jarrerei aurre eginez eta kolektiboa bera ahaldunduz.

Sentsibilizazio-saioan jasotako emaitzetan ikusi dugunez, parte-hartzaileek gaiaren inguruko kezka bazeukatela esan arren, kolektibo horrekiko ezjakintasun eta aurreiritzi asko zeuzkaten saioa egin aurretik. Baina esku-hartzearekin sinesmen horiek aldatu egin ziren, gizarte-bazterketa arriskuan zegoen kolektiboaren mesedetan. Coordinadora Estatal de VIH-Sidak (d.g.) eta Coordinadora Estatal de VIH-Sida eta Grupo de Trabajo sobre Tratamientos del VIHk (2015) esandakoari helduz, kasu honetan gizarte-bazterketa arriskuan dauden pertsonen egoera eta iritzia ezagutzeak balio izan du kolektibo horren ukapena eta bazterketa soziala neurri batean, behintzat, gutxitzeko.

Horregatik guztiagatik, azkeneko ondorio moduan adierazi dezakegu hezkuntza mediatikoa gizartea hezteko erreminta berria eta beharrezkoa dela, gizarte-bazterketa arriskuan dauden kolektiboekin bereziki garrantzitsua izanik, horienganako estereotipoak eta aurreiritziak desagertzeko eta kolektiboaren beraren ahalduntzea emateko, beti ere gizarte integratu, kohesiodun eta anitz baten sorrerako bidean. Hori dela eta, etorkizunari begira ikus-entzunezko hezkuntza eta gaitasun mediatikoaren garapena gizarte-bazterketa arriskuan dauden kolektiboekin lantzea interesgarria izan liteke, kolektiboaren ahalduntzerako baldintzak eman daitezen eta gizarte-mailan kolektiboarekiko egon daitezkeen uste edo jarrera diskriminatzaileekin buka dezagun. 


\section{Bibliografia-aipamenak}

APARICI, R.; GARCÍA, A.; eta FERNÁNDEZ, G. (2006): La imagen. Análisis y representación de la realidad, Bartzelona, Gedisa.

AREA, M. (2004): Los medios y las tecnologías en la educación, Madril, Pirámide.

AREA, M.; GROS, B.; eta MARZAL, M.A. (2008): Alfabetizaciones y tecnologías de la información y la comunicación, Madril, Síntesis.

ASENSIO, M.; eta FERNÁNDEZ, J. (2008): "Violencia machista en los medios de comunicación", Kazetarion Berdinsarea [<http://kazetarionberdinsarea. blogspot.com.es/2008/11/violencia-machistaen-los-medios-de.htmls].

ASOCIACION T4 DE LUCHA CONTRA EL SIDA - HIESAREN AURKAKO T4 ELKARTEA (2016a) [rhttp:// asociaciont4.com>].

BAUMAN, Z. (2003): Modernidad líquida, Fondo de Cultura Económica.

BAZURTO, D. (2014): "Reflexiones en torno a la erradicación del estigma y la discriminación en personas con VIH/SIDA", Temas Antropológicos. Revista Científica de Investigaciones Regionales, 36. bol., 2. zb., 165-171 or. [<https://dialnet. unirioja.es/descarga/articulo/4814663.pdf〉].

BEBEA, I. (2015): Alfabetización digital crítica una invitación a reflexionar y actuar, Madril, Bikore.

BECHDEL, A. (2006): Unos bollos de cuidado, Bartzelona, La Cúpula.

BUSCHMAN, J. (2010): "Alfabetización informacional, 'nuevas' alfabetizaciones y alfabetización”, Boletín de la Asociación Andaluza de Bibliotecarios, 98-99. zb., 155-183 or. [<https:// dialnet.unirioja.es/descarga/articulo/3616432. pdf>].
CABERO, J. (2001): Tecnología educativa. Diseño y utilización de medio en la enseñanza, Bartzelona, Paidós.

CALDEIRO, M.C.; eta AGUADED, I. (2015): “Alfabetización comunicativa y competencia mediática en la sociedad hipercomunicada", Revista Digital de Investigación en Docencia Universitaria, 1. zb., 37-55 or. [<https://dialnet.unirioja.es/ descarga/articulo/5156473.pdf)].

CARBALLEDA, A. (2002): La intervención en lo social: exclusión e integración en los nuevos escenarios sociales. Buenos Aires: Paidós.

CASTELLS, M. (1996): La era de la información, vol. 1. Economía, sociedad y cultura. La sociedad red, Madril, Alianza.

CHOMSKY, N.; eta HERNÁN, E. (1990): Los guardianes de la libertad, Bartzelona: Crítica.

COORDINADORA ESTATAL DE VIH-SIDA (d.g.): Guía de estilo sobre VIH/sida, Cesida [shttp://www. cesida.org/wp-content/uploads/documentos/ documentacion/GuiaEstiloVIH.pdf〉].

COORDINADORA ESTATAL DE VIH-SIDA; eta GRUPO DE TRABAJO SOBRE TRATAMIENTOS DEL VIH (2015): $\mathrm{VIH}$, discriminación y derechos. Guía para personas que viven con el VIH, Cesida [<http:// www.cesida.org/wp-content/uploads/2015/12/ Guia_ESTIGMA_nov2015.pdf)].

CUBELLS, M. (2014): ¿Las tripas de la TV: todo lo que no ves al ver la tele [bideoa], TEDx Talks (ekoizlea) [<https://www.youtube.com/ watch?v=AMMUTgG6408>].

- (2013): ¿Y tú qué miras?, Bartzelona, Roca Editorial.

- (2006): ¿Quién cocina la televisión que comemos? La dieta televisiva y sus cocineros, Bartzelona, Carroggio. 
FERRÉS, J. (2005): “La competencia en comunicación audiovisual: propuesta articulada de dimensiones e indicadores", Quaderns del Consell de l'Audiovisual de Catalunya, 25. zb., 9-17 or. [<http://docplayer.es/4425745-Lacompetencia-en-comunicacion-audiovisualpropuesta-articulada-de-dimensiones-eindicadores.html>].

- (1994): Televisión y educación, Bartzelona, Paidós.

FERRÉS, J.; eta PISCITELLI, A. (2012): “La competencia mediática: propuesta articulada de dimensiones e indicadores", Comunicar. Revista Científica de Comunicación y Educación, XIX. bol., 38. zb., 75-82 or. ['https://doi. org/10.3916/C38-2011-02-08>]

GARCÍA AVILÉS, J.A. (2015): Comunicar en la Sociedad Red. Teorías, modelos y prácticas, Bartzelona, UOC.

GAVARA DE CARA, J.C. (2015): "La alfabetización mediática en el Derecho español" Cuadernos Manuel Giménez Abad, 10. zb., 243-264 or. [«https:// dialnet.unirioja.es/descarga/articulo/5412143. $p d f>]$.

GÉRTRUDIX-BARRIO, F. et al. (2016): “Alfabetización digital, competencias mediáticas y Open Data”, Revista Latinoamericana de Tecnología Educativa, 2. bol.; 15. zb., 114-121 or. [<https://doi. org/10.17398/1695-288X.15.2.113>].

GUTIÉRREZ, A.; eta TYNER, K. (2012): “Educación para los medios, alfabetización mediática y competencia digital", Comunicar. Revista Científica Iberoamericana de Comunicación y Educación, 38. bol., 31-39 or. [<https://doi. org/10.3916/C38-2012-02-03)].

IPUBLIMARKETING (ekoizlea): (2014): The Science of Persuasion [bideoa] [/https://www.youtube. com/watch?v=wpAvy-OB-kQ»].

IZAGIRRE, A. (2011): "En los zapatos del asesino", Pikara Online Magazine [<http://www. pikaramagazine.com/2011/06/en-los-zapatosdel-asesino-los-medios-de-comunicacion-amenudo-construyen-relatos-comprensivos-conlos-agresores-y-muestran-el-asesinato-comofruto-de-un-arrebato/>]

JENATSCH, T.; eta BAUER, R. (2014): Comunicación para el desarrollo: una guía práctica, Berna, Agencia Suiza para el Desarrollo y la Cooperación [<https://www.eda.admin.ch/dam/deza/ es/documents/publikationen/Diverses/ Communication-for-development-Manual ES.pdf $\rangle$.

LOSCERTALES, F.; eta NÚÑEZ, T. (2008): Los medios de comunicación con mirada de género, Granada, Consejería de Igualdad y Asuntos Sociales.

MARCH, M.X. (1997): “Los medios de comunicación social como agentes de comunicación social”, Educación Social. Revista de Intervención Socioeducativa, 7. zb., 21-40 or.

MARTÍNEZ, M.; eta VÁSQUEZ, O. (2016): “Comunicación para la inclusión social de minorías. La clase mágica, un modelo de intervención para el cambio social”, Revista de Ciencias Sociales, 1. bol., 11. zb., 187-209 or. [khttps://doi. org/10.14198/OBETS2016.11.1.08>].

MASTERMAN, L. (1993): La enseñanza en los medios de comunicación, Madril, Ediciones de la Torre.
MASTRODOMÉNICO, H. (2011): "La influencia persuasiva de los estímulos eróticos en la publicidad sobre las tendencias de consumo de los jóvenes", Panorama, 5. bol., 9. zb., 181-202 or. [<https://dialnet.unirioja.es/servlet/ articulo? codigo $=4780036$ >].

MCCOMBS, M. (2006): Estableciendo la agenda. El impacto de los medios en la opinión pública y el conocimiento, Bartzelona, Paidós.

MENDOZA, K.; BELARRA, I.; eta BUSTOS, A.J. (2014): "Repensando el proceso: propuestas críticas para la educación social desde la perspectiva socio-constructivista", Revista de Educación Social, 19. zb., 1-10 or. [<https://www.siis.net/ es/documentacion/catalogo/Record/517035)]

PARENTI, M. (2008): “Manipulación monopolística de los medios", Rebelión [<http://www.rebelion.org/ noticias/2008/10/75072.pdf〉].

PEIRANO, M. (2015): ¿Por qué me vigilan, si no soy nadie? [bideoa], TEDx Talks (ekoizlea) [<https://www. youtube.com/watch?v=NPE7i8wuupk»].

PÉREZ, M.A. (2004): Los nuevos lenguajes de la comunicación. Enseñary aprender con los medios, Bartzelona, Paidós.

PÉREZ, M.A.; eta AGUADED, J.I. (2000): “La educación en medios de comunicación como contexto educativo en un mundo globalizado", in Cabrero, J. (arg.), Nuevas tecnologías aplicadas a la educación, Síntesis, 63-76 or.

POLO, G. (ekoizlea) (2017): VIH y medios de comunicación [ikasleak elaborazio propioz burututako bideoa] [<https://drive.google.com/ file/d/oB_Q uaCrdfxQUNxbootWUV3boE/ view? usp=sharing'].

PONS, A.; eta MARTÍNEZ, C. (2010): "Otra víctima más", Pikara Online Magazine [<http://www. pikaramagazine.com/2010/11/otra-victimamas-banalizacion-y-doble-discurso-ante-laviolencia-de-genero/s].

POSTMAN, N. (1985): Amusing Ourselves to Death: Public Discourse in the Age of Show Business, Penguin.

PRODUCCIONES CMI; eta PAZ CON DIGNIDAD-OMAL (ekoizlea). (2014): Una mosca en una botella de Coca-Cola [bideoa] [<https://www.youtube. com/watch?v=SIDrAfArRMY)].

RAMONET, I. (2009): “Control social total”, Le Monde Diplomatique en Español, 163. zb., 1 or. [rhttp://www.medelu.org/IMG/pdf/EDITORIAL_ RAMONET_mayoo9.pdf〉].

RENÉS, P.; GARCÍA, R.; eta RAMÍREZ, A. (2013): "Competencia mediática y buenas prácticas en contextos inclusivos", Multiárea, 6. zb., 387408 or. [khttp://www.uclm.es/cr/educacion/ $\mathrm{pdf} /$ revista/6.pdf $\rangle]$.

ROMEO, M.; eta MARCHI, D. (2015): "Relación del conocimiento y el ejercicio de derechos con el estigma y discriminación de personas viviendo con VIH", Actualizaciones en SIDA e Infectología, 23. bol., 89. zb., 58-68 or. ['http://infectologia.info/wp-content/ uploads/2016/07/89-3.pdf>].

SERRANO, P. (2010): Desinformación: cómo los medios ocultan el mundo, Bartzelona, Península. 
TORRES, A. (2009): "La educación para el empoderamiento y sus desafíos", Sapiens, 1. zb., 89-108 or. [<https://dialnet.unirioja.es/descarga/ articulo/3175951.pdf>].

VALENCIA, J.; eta MAGALLANES, C. (2015): “Prácticas comunicativas y cambio social: potentia, acción y reacción", Universitas Humanística, 81. zb., 15-31 or. [/http://revistas.javeriana. edu.co/index.php/univhumanistica/article/ view/14885/12020>].

VÁSQUEZ, A. (2008): “Individualismo, modernidad líquida y terrorismo hipermoderno: de Bauman a Sloterdijk", Konvergencias. Filosofía y Culturas en Diálogo, 5. bol., 17. zb., 122-130 or. [khttp:// www.konvergencias.net/vasquezrocca168. pdf>].

ZAPATA, M. A. (2014): “Las estrategias estéticas en la publicidad: un recorrido por los juegos de la persuasión" [doktore tesia], Medellín, Universidad Nacional de Colombia [<http://www.bdigital.unal.edu. co/11884/1/98666336.2013.pdf>].

ZUBIRIA, P. (2016): “Ondo konektatuta, ondo kontrolatuta: ikusi zenbat dakizun Ton Siedsmaz", Argia [<http://www.argia.eus/argia-astekaria/2499/ ondo-konektatua-ondo-kontrolatuta-ikusizenbat-dakizun-ton-siedsmaz〉]. 